\title{
EFEKTIFITAS ASUHAN GIZI TERHADAP KEPATUHAN ASUPAN NATRIUM DAN PROTEIN PADA PASIEN HIPERTENSI DENGAN GAGAL GINJAL KRONIK DI RSUD Dr. SAIFUL ANWAR MALANG
}

\author{
Ismi Ningtyas*, Meilany Purnamasari Sudardjo*, Nabilahasna Nafisah, Sukarlin**, \\ Inggita Kusumastuty* $\bowtie$
}

\begin{abstract}
Abstrak
Asuhan gizi adalah kegiatan yang dilakukan oleh ahli gizi berupa pemberian diet dan edukasi/ konseling gizi serta kolaborasi dengan tenaga kesehatan lain yang dapat membantu dalam menunjang proses penyembuhan pasien. Asuhan gizi pada pasien hipertensi dengan gagal ginjal kronik di RSUD Dr. Saiful Anwar ini bertujuan untuk mengetahui apakah asuhan gizi yang diberikan efektif terhadap kepatuhan asupan natrium dan protein pada pasien hipertensi dengan gagal ginjal kronik. Desain penelitian ini adalah rancangan penelitian korelasional dengan jenis pendekatan cross-sectional pada 30 orang responden yang dipilih secara purposive sampling. Data penelitian diperoleh melalui rekam medis pasien dan food record selama 3 hari. Analisis data dilakukan menggunakan uji Pearson (asupan protein) dan uji Spearman (asupan natrium). Hasil penelitian menunjukkan bahwa terdapat hubungan yang signifikan antara asuhan gizi yang diberikan dengan asupan protein pasien $(p=0,002)$. Tidak terdapat hubungan yang signifikan antara asuhan gizi yang diberikan dengan asupan natrium pasien $(p=0,943)$. Sebanyak $56,7 \%$ pasien memiliki output urin $>60 \%$ asupan cairannya dan $40 \%$ memiliki output urin $<60 \%$ asupan cairannya. Dapat disimpulkan bahwa asuhan gizi yang diberikan mempengaruhi asupan protein pasien, namun tidak pada asupan natrium. Keseimbangan cairan pasien dilihat dari output urin didapatkan sebagian besar lebih banyak dan atau lebih sedikit dari asupan cairannya.
\end{abstract}

Kata kunci: asuhan gizi, asupan protein, asupan natrium, hipertensi, keseimbangan cairan, gagal ginjal kronik.

\section{EFFECTIVITY NUTRITIONAL CARE TO COMPLIANCE NATRIUM INTAKE, PROTEIN INTAKE OF HYPERTENSIVE PATIENT WITH CHRONIC KIDNEY DISEASE IN RSUD Dr. SAIFUL ANWAR MALANG}

\begin{abstract}
Nutrition care is activity which carried out by nutritionist the provision of education or diet and nutrition counseling and collaboration with other health workers to help in supporting the process of healing hypertension patients with chronic kidney disease in RSUD dr. Saiful Anwar Malang. This research aims to find out whether nutrition care is effective towards natrium intake, protein intake, and fluid balance of hypertensive patients with chronic kidney disease in RSUD Dr. Saiful Anwar Malang. The design of this research is correlational research scheme with the type of cross-sectional approach to 30 respondents that selected through Purposive Sampling. The research data obtained from patient medical records and food records for 3 days. Data analysis was performed by using the Pearson Test (protein intake), Spearman Test (natrium intake). The results showed that there was a significant relationship between the nutritional care provided and patient protein intake $(p=0,002)$. There is no significant relationship between nutritional care and patient natrium intake $(p=0,943)$. As many as $56.7 \%$ of patients had a urine output $>60 \%$ of their fluid intake and $40 \%$ had a urine output $<60 \%$ of their fluid intake. Therefore, it can be concluded that nutritional care given affects the patient's protein intake but not natrium intake. The patient's fluid balance can be seen from urine output is found to be mostly more or less than his fluid intake.
\end{abstract}

Keywords: chronic kidney disease, fluid balance, hypertension, nutritional care, natrium intake, protein intake.

*Program Studi Profesi Dietisien, Fakultas Kedoktean, Universitas Brawijaya

**Instalasi Gizi, RSUD Dr. Saiful Anwar Malang

E-mail: inggita@ub.ac.id 


\section{Pendahuluan}

Hipertensi menjadi penyebab kematian ke-3 setelah stroke dan tuberculosis dengan proporsi $6,7 \%$ dari semua populasi kematian semua umur di Indonesia. ${ }^{1}$ Prevalensi hipertensi di Indonesia pada kelompok umur $\geq 18$ tahun adalah sebesar $25,8 \%$ dan meningkat menjadi $34,11 \%$ pada tahun 2018 dan prevalensi di Jawa Timur pada tahun 2013 sebesar 26,2\% menjadi 36,32\%.2 Di Kota Malang pada tahun 2014 hipertensi merupakan salah satu penyakit yang masuk ke dalam sepuluh besar kejadian penyakit terbanyak dengan 58.046 kasus. Dari 43.855 orang yang melakukan pengukuran tekanan darah di pelayanan kesehatan, terdapat $35,92 \%$ orang dikategorikan ke dalam hipertensi. ${ }^{3}$ Menurut Babatsikou dan Zavitsanou salah satu faktor yang dapat mempengaruhi risiko terjadinya hipertensi adalah asupan natrium yang berlebih. ${ }^{4}$ Natrium yang tinggi dapat menyebabkan tubuh meretensi cairan, sehingga meningkatkan volume darah. Volume darah yang meningkat menyebabkan jantung memompa lebih keras untuk mendorong volume darah yang meningkat dan menjadi hipertensi. ${ }^{5}$

Peningkatan tekanan darah yang berlangsung kronis pada pembuluh arteriol kecil dan glomeruli dapat menyebabkan sclerosis sehingga terjadi nefrosklerosis dan menyumbat pembuluh darah tersebut. 6 Penyumbatan tersebut mengakibatkan glomerulus dan atrofi tubulus menjadi rusak, sehingga seluruh nefron rusak dan terjadi gagal ginjal kronik. ${ }^{7}$ Hipertensi menjadi penyebab utama kejadian gagal ginjal kronik, yaitu sebesar $34 \%$ dan pada tahun 2012 menjadi penyebab gagal ginjal kelima dengan angka sebesar 8,5\%.8 Prevalensi kejadian gagal ginjal kronik pada penduduk umur $\geq 15$ tahun di Indonesia tahun 2013 sebesar $0,2 \%$ dan meningkat menjadi sebesar $0,38 \%$ pada tahun 2018. Menurut hasil Riskesdas prevalensi kejadian gagal ginjal kronik di Jawa Timur pada tahun 2018 sebesar $0,29 \%$.

Selain itu, penurunan fungsi ginjal yang progresif salah satunya ditandai dengan adanya protein dalam urin dan kenaikan tingkat ureum atau kreatinin (sisa produksi metabolisme protein) dalam darah. Hal tersebut yang menyebabkan perlu adanya pembatasan asupan protein pada penderita gagal ginjal kronik. ${ }^{7}$ Kondisi penyakit yang tidak terkendali dapat disebabkan karena pengetahuan dan kesadaran pasien yang kurang. Pengetahuan dan sikap pasien mempengaruhi kepatuhan pasien dalam pengendalian penyakit, salah satu kepatuhan pasien dapat dilihat dari asupan makan pasien. ${ }^{10}$ Proses asuhan gizi terstandar oleh ahli gizi di rumah sakit dilakukan dengan memberikan intervensi yang sesuai dengan diagnosis gizi berdasarkan penyebab masalah yang dialami pasien. Intervensi berupa pemberian diet dan edukasi atau konseling gizi sesuai dengan kebutuhan pasien, sehingga kepatuhan pasien terhadap asupan dapat dilihat sebagai monitoring dan evaluasi efektif atau tidaknya asuhan gizi yang sudah diberikan. ${ }^{11}$

Berdasarkan pemaparan di atas, penulis tertarik untuk meneliti terkait apakah asuhan gizi yang diberikan efektif terhadap kepatuhan asupan natrium dan protein pada pasien hipertensi dengan gagal ginjal kronik di RSUD Dr. Saiful Anwar.

\section{Bahan dan Metode}

Penelitian ini merupakan survei kuantatif dengan pengambilan data secara cross sectional untuk melihat korelasi atau efektifitas dari pemberian asuhan gizi terhadap kepatuhan asupan natrium dan protein pada pasien hipertensi dengan gagal ginjal kronik. Populasi dalam penelitian ini adalah seluruh pasien hipertensi dengan gagal ginjal kronik di ruang rawat inap RSUD Dr. Saiful Anwar Malang. Besar sampel dalam penelitian ini sebanyak 30 responden yang diambil dengan cara purposive sampling. 
Kriteria inklusi dalam penelitian ini adalah pasien hipertensi dengan gagal ginjal kronik yang berada di ruang rawat inap IRNA I RSUD Dr. Saiful Anwar $\geq 3$ hari, berusia $>25$ tahun dan bersedia menjadi subjek penelitian dengan menandatangani informed consent. Kriteria eksklusi adalah pasien rawat jalan atau pasien rawat inap $<3$ hari dengan catatan dan data laboratorium yang tidak lengkap.

Pada penelitian ini, variabel independen adalah asuhan gizi yang diberikan oleh ahli gizi berupa pemberian diet dan edukasi atau konseling pada pasien hipertensi dengan gagal ginjal kronik. Variabel dependen adalah asupan natrium dan protein pada pasien hipertensi dengan gagal ginjal kronik. Alat ukur yang digunakan adalah rekam medis pasien dan formulir food record. Food record dilakukan selama $3 \times 24$ jam yang berisi bahan makanan apa saja yang dikonsumsi beserta jumlahnya dan input cairan yang diperoleh secara peroral serta output urin dengan cara mewawancarai pasien.

Data yang diperoleh dilakukan analisis univariat untuk mengetahui gambaran distribusi frekuensi dari data karakteristik responden (usia, jenis kelamin, pendidikan, pekerjaan, kelas perawatan dan jenis diet) serta asupan protein yang dikategorikan menjadi kurang $(<80 \%)$, baik $(80-110 \%)$ dan berlebih $(>110 \%)$, asupan natrium yang dikategorikan menjadi baik ( $\leq$ standar) dan berlebih (>standar), serta keseimbangan cairan yang dikelompokan menjadi output urin $<60 \%$, sama dengan $60 \%$ dan $>60 \%$ dari asupan cairan oral. Kemudian dilakukan uji normalitas Saphiro Wilk dan dilanjutkan dengan analisis bivariat menggunakan uji korelasi Pearson untuk asupan protein (data terdistribusi normal) dan uji korelasi Spearman untuk asupan natrium (data berdistribusi tidak normal). Uji ini dilakukan untuk mengetahui efektifitas asuhan gizi terhadap kepatuhan asupan natrium dan protein pada pasien hipertensi dengan gagal ginjal kronik di ruang rawat inap IRNA I RSUD Dr. Saiful Anwar Malang.
Penelitian ini telah melakukan uji kelaikan etik pelaksanaan penelitian di RSUD Dr. Saiful Anwar dengan nomor 400/089/K.3/302/2019.

\section{Hasil}

Jumlah responden yang memenuhi kriteria inklusi dan telah bersedia mengikuti penelitian ini adalah sebesar 30 orang responden. Pada Tabel 1 ditunjukkan karakteristik responden.

Jenis diet yang diberikan pada pasien responden penelitian sebagian besar adalah diet rendah protein, normal protein, diet hemodialisa (tinggi protein) serta diet rendah garam. Bentuk makanan yang diberikan bisa berupa makanan biasa maupun makanan cair yang diasup melalui oral.

Pada Tabel 2 ditunjukkan hasil analisis univariat pada persentase asupan protein dan natrium serta keseimbangan cairan pasien berdasarkan asupan cairan oral dan output urin pada Tabel 3. Selain itu, juga ditunjukkan hasil analisis bivariat pada persentase asupan protein dan natrium pasien dengan standar diet rumah sakit yang diberikan oleh ahli gizi berdasarkan asuhan gizinya. Untuk keseimbangan cairan tidak dilakukan analisis bivariat dikarenakan belum terdapat standar kebutuhan cairan tertulis dari asuhan gizi yang diberikan.

Berdasarkan hasil uji normalitas, dapat diketahui bahwa data asupan protein terdistribusi normal, namun data asupan natrium tidak terdistribusi normal. Sehingga dari hasil penelitian, didapatkan bahwa dengan uji Pearson diperoleh $p$ value -sebesar 0,002, yang menunjukkan ada hubungan yang signifikan antara asuhan gizi yang diberikan berupa pelayanan makan dan edukasi gizi berdasarkan standar diet protein RS (rendah protein, normal protein, dan tinggi protein) dengan asupan protein pasien. 
Tabel 1. Distribusi karakteristik responden.

\begin{tabular}{|c|c|c|}
\hline \multirow{2}{*}{ Kategori } & \multicolumn{2}{|c|}{ Total Responden } \\
\hline & $\mathrm{n}$ & $\%$ \\
\hline \multicolumn{3}{|l|}{ Usia } \\
\hline 25-59 tahun & 23 & 76,7 \\
\hline$\geq 60$ tahun & 7 & 23,3 \\
\hline \multicolumn{3}{|l|}{ Jenis Kelamin } \\
\hline Laki-laki & 12 & 40 \\
\hline Perempuan & 18 & 60 \\
\hline \multicolumn{3}{|l|}{ Pendidikan Terakhir } \\
\hline SD & 7 & 23,3 \\
\hline SMP & 8 & 26,7 \\
\hline SMA & 14 & 46,7 \\
\hline Perguruan Tinggi & 1 & 3,3 \\
\hline \multicolumn{3}{|l|}{ Pekerjaan } \\
\hline Tidak bekerja & 12 & 40 \\
\hline PNS/TNI/POLRI & 2 & 6,7 \\
\hline Wiraswasta & 4 & 13,3 \\
\hline Karyawan swasta & 11 & 36,7 \\
\hline Petani/buruh & 1 & 3,3 \\
\hline \multicolumn{3}{|l|}{ Kelas Perawatan } \\
\hline Kelas I & 8 & 26,7 \\
\hline Kelas II & 9 & 30 \\
\hline Kelas III & 13 & 43,3 \\
\hline \multicolumn{3}{|l|}{ Jenis Diet } \\
\hline Rendah Protein (RP) & 3 & 10 \\
\hline Rendah Protein Rendah Garam (RPRG) & 10 & 33,3 \\
\hline Cair Rendah Protein (C.RP), oral & 1 & 3,3 \\
\hline $\begin{array}{l}\text { Makanan Saring I +Cair Rendah Protein } \\
\text { (MS I+C.RP) }\end{array}$ & 1 & 3,3 \\
\hline Diabetes Melitus Rendah Protein Rendah & 1 & 3,3 \\
\hline \multicolumn{3}{|l|}{ Garam (DMRPRG) } \\
\hline Diabetes Melitus Normal Protein Rendah & 2 & 6,7 \\
\hline \multicolumn{3}{|l|}{ Garam (DMNPRG) } \\
\hline Hemodialisa I (HD I) & 2 & 6,7 \\
\hline Hemodialisa I Rendah Garam (HD I RG) & 7 & 23,3 \\
\hline Hemodialisa II (HD II) & 1 & 3,3 \\
\hline Hemodialisa II Rendah Garam (HD II RG) & 2 & 6,7 \\
\hline
\end{tabular}


Untuk asupan natrium, didapatkan bahwa dengan uji Spearman diperoleh $p$-value sebesar 0,943, yang menunjukkan bahwa tidak ada hubungan yang signifikan antara asuhan gizi yang diberikan berupa pelayanan makan dan edukasi gizi berdasarkan standar diet natrium RS (rendah garam $800 \mathrm{mg}$ dan tidak rendah garam $1200 \mathrm{mg}$ ) dengan asupan natrium pasien. Hasil penelitian ini dapat dilihat pada Tabel 5 .

Tabel 2. Distribusi frekuensi standar diet RS dengan persentase asupan protein.

\begin{tabular}{llllll}
\hline & \multicolumn{5}{c}{ Standar Diet Protein RS (Asuhan Gizi) } \\
\cline { 2 - 6 } Persentase asupan & Rendah & Normal & Tinggi & & \\
protein pasien & Protein & Protein & Protein & Total & p-value \\
& $n=16$ & $n=9$ & $n=5$ & & \\
& $n(\%)$ & $n(\%)$ & $n(\%)$ & $n(\%)$ & \\
\hline Kurang & $8(26,7)$ & $7(23,3)$ & $2(6,7)$ & $17(56,7)$ & \\
Baik & $7(23,3)$ & $2(6,7)$ & $3(10)$ & $12(40)$ & 0,522 \\
Berlebih & $1(3,3)$ & $0(0)$ & $0(0)$ & $1(3,3)$ & \\
\hline
\end{tabular}

Keterangan: $p>0,05$; Chi Square

Tabel 3. Distribusi frekuensi standar diet RS dengan persentase asupan natrium.

\begin{tabular}{lcccc}
\hline & \multicolumn{4}{c}{ Standar Diet Natrium RS (Asuhan Gizi) } \\
\cline { 2 - 5 } Persentase & Rendah Garam & Tidak Rendah Garam & & \\
asupan natrium & $800 \mathrm{mg}$ & $1200 \mathrm{mg}$ & Total & p-value \\
pasien & $\mathrm{n}=23$ & $\mathrm{n}=7$ & & \\
& $\mathrm{n}(\%)$ & $\mathrm{n}(\%)$ & $\mathrm{n}(\%)$ & \\
\hline Baik & $17(56,7)$ & $4(13,3)$ & $21(70)$ & \multirow{2}{*}{0,397} \\
Berlebih & $6(20)$ & $3(10)$ & $9(30)$ & \\
\hline
\end{tabular}

Keterangan: $p>0,05$; Chi Square

Tabel 4. Distribusi frekuensi keseimbangan cairan.

\begin{tabular}{cl}
\hline Persentase Keseimbangan Cairan & \multicolumn{1}{c}{$\mathrm{n}(\%)$} \\
\hline$<60 \%$ & $12(40)$ \\
$=60 \%$ & $1(3,3)$ \\
$>60 \%$ & $17(56,7)$ \\
\hline
\end{tabular}

Tabel 5. Hubungan standar diet RS dengan asupan protein dan natrium.

\begin{tabular}{lll}
\hline \multirow{2}{*}{ Variabel } & \multicolumn{2}{c}{ Standar Diet RS (Asuhan Gizi) } \\
\cline { 2 - 3 } & mean \pm SD / median(P25-P75) & p-value \\
\hline Asupan Protein & $35,2 \pm 17$ & $0,002^{*}$ \\
Asupan Natrium & $824,3(796,7-924,9)$ & 0,943 \\
\hline
\end{tabular}

Keterangan:*terdapat hubungan signifikan dengan nilai $p<0,05$; Pearson 


\section{Pembahasan}

\section{Hubungan Asuhan Gizi dengan Asupan Protein}

Asupan protein responden diperoleh dari hasil wawancara dengan menggunakan form food record selama 3x24 jam yang dianalisis menggunakan software nutrisurvey. Asupan protein dibedakan menjadi 3 kategori yaitu kurang $(<80 \%)$ baik $(80-110 \%)$ dan berlebih $(>110 \%)$. Hasil penelitian menunjukkan bahwa terdapat hubungan yang signifikan antara asuhan gizi yang diberikan dengan asupan protein pasien.

Intervensi yang diberikan dalam asuhan gizi berupa perencanaan diet, edukasi gizi dan kolaborasi gizi yang disesuaikan dengan diagnosis yang ditegakkan berdasarkan akar masalah yang ditemukan dalam assessment. ${ }^{11}$ Pemberian makan di rumah sakit merupakan salah satu bentuk intervensi yang diberikan oleh ahli gizi, asupan yang tidak sesuai dengan kebutuhan (berlebih atau kurang) dapat meningkatkan risiko komplikasi terhadap penyakit dan mempengaruhi status gizi pasien selama di rumah sakit. ${ }^{12}$ Berdasarkan hasil penelitian Kusumayanti, di beberapa rumah sakit pasien yang menderita penyakit noninfeksi masuk rumah sakit dalam keadaan malnutrisi sebanyak 68,57\% diakibatkan karena faktor asupan energi dan protein yang tidak adekuat. ${ }^{13}$ Salah satu faktor yang menyebabkan asupan protein tidak adekuat adalah pasien belum mengetahui secara pasti jumlah protein yang harus dipenuhi. ${ }^{14}$ Berdasarkan hasil penelitian Handayani menunjukkan bahwa adanya peningkatan asupan menjadi good diet pada pasien di Rumah Sakit Umum Daerah Sidoarjo setelah diberikan asuhan gizi. ${ }^{15}$

Kebutuhan protein untuk penderita gagal ginjal tanpa hemodialisa $0,6-0,8 \mathrm{~g} / \mathrm{kgBB} / \mathrm{hari}$, dengan hemodialisa sebesar 1,2-1,4 g/kgBBI/ hari, dengan CAPD 1,2-1,5 g/kgBBI/hari dan dianjurkan sebesar $50 \%$ asupan protein berasal dari pangan yang bernilai biologis tinggi. 16,17 Oleh karena itu, diperlukan adanya asuhan gizi agar asupan protein pasien sesuai dengan kebutuhan.

Asupan protein sangat mempengaruhi proses penyembuhan dari penderita gagal ginjal. Penurunan fungsi ginjal mengakibatkan ginjal tidak bisa mengeluarkan produk sisa hasil metabolisme protein seperti ureum dan kreatinin.6,18 Penumpukan ureum dan kreatinin di dalam tubuh menyebabkan gangguan multi sistem termasuk pada organ gastrointestinal seperti mual dan muntah. 1,19,20 Berdasarkan hasil observasi dalam penelitian ini, sebanyak $56,7 \%$ asupan protein kurang dari kebutuhan disebabkan sebagian besar pasien mengalami penurunan nafsu makan akibat rasa makanan yang disediakan tidak sesuai dengan selera serta adanya mual dan muntah. Penelitian Sumiasih menunjukkan bahwa adanya hubungan antara asupan protein hewani dengan kadar ureum dan kreatinin pada penderita gagal ginjal kronik. ${ }^{21}$

Hasil penelitian menunjukkan bahwa sebanyak $3,3 \%$ asupan protein pasien berlebih. Berdasarkan hasil observasi dalam penelitian ini asupan protein berlebih disebabkan karena pasien mengkonsumsi makanan luar rumah sakit. Hal ini menggambarkan kurang patuhnya pasien terhadap diet yang diberikan. Penelitian Yunita menyebutkan bahwa pasien yang mengkonsumsi makanan dari luar rumah sakit disebabkan karena pasien tidak diberikan edukasi secara rutin oleh ahli gizi, sehingga tidak termotivasi untuk mematuhi diet yang diberikan. ${ }^{22}$

\section{Hubungan Asuhan Gizi dengan Asupan Natrium}

Asupan natrium responden didapatkan dari hasil wawancara dengan menggunakan formulir food record selama $3 \times 24$ jam. Proses wawancara dilakukan selama pasien mendapatkan asuhan gizi yang diberikan oleh ahli gizi saat rawat inap. 
Hasil penelitian menunjukkan bahwa tidak ada hubungan yang signifikan antara asuhan gizi yang diberikan dengan asupan natrium pasien.

Hasil penelitian ini bertolak belakang dengan penelitian yang dilakukan oleh Hendriyani yaitu terdapat hubungan yang bermakna antara pengetahuan, sikap dan praktek pemilihan makanan tinggi natrium dengan asupan natrium seseorang. ${ }^{24}$ Namun, penelitian yang dilakukan oleh Kamran menunjukkan bahwa tidak terdapat hubungan yang bermakna antara pengetahuan dan persepsi penyakit pada pasien hipertensi dengan asupan natrium. ${ }^{25} \mathrm{Hal}$ tersebut disebabkan karena beberapa individu tidak memiliki informasi yang cukup terkait asupan garam setiap harinya. ${ }^{26}$

Pengetahuan yang kurang inilah yang dapat meningkatkan asupan natrium pada pasien. Selain itu, perbedaan tingkat pengetahuan pada pasien dapat menyebabkan pasien menerima informasi yang salah seperti hipertensi tidak boleh mengkonsumsi garam. ${ }^{27}$ Selain tingkat pengetahuan, dukungan keluarga juga dapat berkontribusi dalam asupan natrium pasien hipertensi, apabila dukungan keluarga baik maka asupan natrium pasien dapat terkontrol begitu sebaliknya apabila dukungan keluarga tersebut rendah maka asupan natrium pasien akan berlebih karena pasien dapat dengan bebas mengkonsumsi makanan yang diinginkan. ${ }^{28}$

Pada dasarnya asupan natrium pada penderita hipertensi dapat digolongkan menjadi 3 yaitu diet rendah garam 1 (200 $400 \mathrm{mg}$ natrium), diet rendah garam 2 (600 $800 \mathrm{mg}$ natrium) dan diet rendah garam 3 (1000- $1200 \mathrm{mg}$ natrium). Namun, dalam penelitian kali ini, asupan responden dibandingkan dengan diet rendah garam 2 yaitu $800 \mathrm{mg}$ natrium. Hal tersebut disebabkan karena diet rendah garam 2 merupakan standar diet Rumah Sakit Dr. Saiful Anwar Malang yang digunakan dalam pemberian intervensi rendah garam. Namun, apabila pasien tidak diberikan diet rendah garam maka pasien diberikan natrium sesuai dengan diet rendah garam 3 yaitu 1000-1200 mg natrium.

Konsumsi natrium yang tinggi dapat mengecilkan diameter arteri sehingga jantung harus bekerja lebih keras agar mampu menyalurkan darah yang menyebabkan tekanan darah meningkat. ${ }^{29}$ Selain itu, meningkatnya cairan ektraseluler karena komposisi natrium dalam cairan ektraseluler meningkat menyebabkan meningkatnya volume darah dan berpengaruh terhadap terjadinya hipertensi. ${ }^{30}$

Penelitian ini didapatkan bahwa asuhan gizi yang diberikan yaitu edukasi gizi dan intervensi gizi tidak berpengaruh terhadap asupan natrium pasien. Sejalan dengan hasil penelitian Kamran yang menunjukkan bahwa tidak ada hubungan antara pengetahuan dan persepsi penyakit pada pasien hipertensi dengan asupan natrium. ${ }^{25}$

\section{Keseimbangan Cairan}

Keseimbangan cairan dianalisis menggunakan uji univariat yang dilihat dari asupan cairan peroral pasien yang dibandingkan dengan output urin selama 3×24 jam yang diperoleh dari hasil wawancara menggunakan form food record. Berdasarkan hasil analisis menunjukkan bahwa sebagian besar pasien memiliki output urin $<60 \%$ dan $>60 \%$ asupan cairannya.

Berdasarkan hasil penelitian sebesar $40 \%$ responden output urin $<60 \%$. Hal ini disebabkan karena terganggunya fungsi ginjal dalam mengeluarkan cairan melalui urin. ${ }^{6,18}$ Pada penyakit gagal ginjal, tubulus akan mengalami kehilangan kemampuan secara progresif, sehingga ginjal tidak mampu untuk mengeluarkan urin yang cukup dan menyebabkan terjadinya edema atau penumpukan cairan atau oliguria, yaitu terganggunya fungsi ginjal dalam mempertahankan homeostasis cairan tubuh dengan kontrol volume cairan. ${ }^{31}$ 
Penelitian yang dilakukan Tovvazi dan Mazzoni menunjukkan bahwa sebanyak 35\% responden mengalami peningkatan berat badan hingga mencapai $2,4 \mathrm{~kg}$ yang disebabkan karena terjadi penumpukan cairan dalam tubuh.32 Hal ini diperkuat dengan hasil penelitian Istanti yang menyebutkan bahwa $60-80 \%$ pasien gagal ginjal yang menjalani hemodialisa meninggal akibat kelebihan cairan. ${ }^{33}$

Selain itu, hasil penelitian menunjukkan sebanyak $56,7 \%$ pasien memiliki output urin $>60 \%$ dari total asupan cairan secara peroral. Hal ini disebabkan karena intake cairan pasien secara peroral kurang dari kebutuhan. Kebutuhan cairan untuk pasien hemodialisa adalah $1000+$ urin, sedangkan kebutuhan cairan untuk pasien yang belum melakukan hemodialisa tidak terbatas apabila produksi urin normal. ${ }^{16}$ Oleh karena itu, diperlukan adanya edukasi gizi terkait cairan yang dibutuhkan pasien gagal ginjal tanpa dan dengan hemodialisa. Keluarga dapat menjadi faktor yang berpengaruh terhadap asupan cairan pasien. Berdasarkan hasil penelitian Setia menunjukkan bahwa asupan cairan pasien dapat dipengaruhi oleh adanya dukungan keluarga, sehingga edukasi dapat diberikan kepada keluarga pasien. ${ }^{34}$

Penelitian ini belum mampu membuktikan bahwa asuhan gizi memiliki hubungan dengan keseimbangan cairan pada pasien gagal ginjal karena tidak memiliki $p$ value pada uji statistik. Hal ini disebabkan karena keterbatasan data yang diperoleh dan waktu pelaksanaan penelitian. Namun, penelitian ini memberikan gambaran bahwa sebanyak $40 \%$ responden memiliki output urin $<60 \%$ dan sebanyak $56,7 \%$ responden memiliki output urin $>60 \%$ asupan cairannya.

Berdasarkan hasil penelitian menunjukkan bahwa asuhan gizi yang diberikan dapat berkontribusi dalam penyediaan diet yang tepat dan pemberian edukasi/konseling gizi agar pasien dan keluarga pasien dapat me- matuhi diet yang diberikan. Asuhan gizi belum diberikan secara optimal pada keseluruhan pasien yang ditangani hal ini disebabkan karena tidak imbangnya ahli gizi dengan jumlah pasien yang ada. Tidak optimalnya pemberian edukasi/konseling gizi pada pasien dan keluarga pasien menyebabkan keluarga pasien memberikan makanan dari luar rumah sakit yang membuat pasien mengkonsumsi makanan yang tidak sesuai dengan diet yang dianjurkan. Selain itu, keluarga yang bergantian menjaga pasien membuat beberapa anggota keluarga tidak mengetahui anjuran diet yang sudah disampaikan ahli gizi dan tidak adanya keinginan untuk berubah dari pasien membuat pasien tetap mengkonsumsi makanan yang tidak sesuai dengan anjuran

\section{Kesimpulan}

Berdasarkan hasil penelitian menunjukkan bahwa asuhan gizi yang diberikan mempengaruhi asupan protein pasien, namun tidak mempengaruhi asupan natrium pasien. Keseimbangan cairan pasien dilihat dari output urin didapatkan sebagian besar lebih banyak dan atau lebih sedikit dari asupan cairannya.

\section{Saran}

Memberikan motivasi kepada pasien dan keluarga melalui edukasi atau konseling gizi, sehingga pasien dapat mematuhi diet yang telah diberikan ahli gizi sesuai dengan kebutuhannya selama di rumah sakit sampai dengan pasien keluar dari rumah sakit. Perlu adanya data terkait output urin pasien di rekam medik. Selain itu, perlu adanya data input cairan pasien peroral dan parenteral sebagai monitoring dan evaluasi keseimbangan cairan pasien. 


\section{Daftar Pustaka}

1. Kemenkes. Pemberantasan Penyakit Menular dan Penyehatan Lingkungan. Kemenkes RI. 2013.

2. Riskesdas. Badan Penelitian dan Pengembangan Kesehatan Kementerian Kesehatan RI. Jakarta: Riskesdas RI. 2013.

3. Dinkes Kota Malang. Profil Kesehatan Kota Malang. Malang: Depkes Malang. 2014.

4. Babatsikou F, Zavitsanou A. Epidemiology of Hypertension In The Elderly. Health Sci J. 2010; 4(1):24-30.

5. Mulki R. Hubungan Antara Asupan Natrium, Asupan Kalium, Rasio Asupan Natrium: Kalium dengan Tekanan Darah pada Pasien Puskesmas Pasir Kaliki Kecamatan Cicendo Kota Bandung. Bandung: Politeknik Kesehatan Kemenkes. 2014.

6. Guyton A, Hall J. Buku Ajar Fisiologi Kedokteran. Edisi ke-12. Jakarta: EGC. 2014.

7. Budiyanto C. Hubungan Hipertensi dan Diabetes Mellitus terhadap Gagal Ginjal Kronik. Kedokteran Islam. 2009.

8. PERNEFRI. 5th Annual Report of IRR. Pehimpunan Nefrologi Indonesia. 2012.

9. Pasticci F, Fantuzzi A, Pegoraro M. Nutritional Management Stage 5 of Chronic Kidney Disease. J Ren Care. 2012; 38(1).50-8.

10. Busari O. Impact of Patients Knowledge, Attitude and Practice on Hypertension on Compliance with Antihypertensive Drugs in a Resource-poor Setting. TAF Prev Med Bull. 2010; 9(2):87-92.

11. Sumapradja M, Fayakun $Y$, Widyastuti $D$. Proses Asuhan Gizi Terstandar (PAGT). Abadi Publ Dan Print. 2011.

12. Braunschweig $C$, Gomez $S$, Sheean $P$. Impact of Decline in Nutrition Status of Outcome in Adult Patient Hospitalized for More Than 7 Days. J Am Diet Assoc.
2000; 1001(13):16-22.

13. Kusumayanti I, Hadi H, Susetyowati. Faktor - Faktor yang Mempengaruhi Kejadian Malnutrisi Pasien Dewasa di Ruang Rawat Inap. J Gizi Klin Indones. 2004; 1(1):9-17.

14. Irma I, Isti S, Elza I. Hubungan Asupan Protein dengan Kadar Ureum dan Kreatinin pada Pasien Gagal Ginjal Kronik yang sedang Menjalani Hemodialisa di Unit Hemodialisa RS PKU Muhammadiyah Yogyakarta. J Nutr. 2017; 19(1):1-6.

15. Handayani D, Astuti P, Nurwati $Y$, Marselina AM. Efektifitas Penatalaksanaan Proses Asuhan Gizi Terstandar Terhadap Perbaikan Asupan Pasien Sindrom Metabolik di RSUD Sidoarjo. 2017.

16. Cano N. ESPEN Guidelines on Enteral Nutrition: Adult Renal Failure. Clin Nutr. 2006; 25:295-310.

17. Almatsier S. Penuntun Diet. Jakarta: Gramedia Pustaka Utama. 2010.

18. Sherwood. Fisiologi Manusia dari Sel ke Sistem. Edisi ke-6. Jakarta: EGC. 2012.

19. Levey A, Bosch J, Lewis J, Greene T. A More Accurate Method To Estimate Glomerular Filtration Rate From Serum Creatinine: A New Prediction Equation,Modification of Diet in Renal DiseaseStudy Group. Ann Int Med. 2011; 130:461-70.

20. Martini. Hubungan Tingkat Asupan Protein dengan Kadar Ureum dan Kreatinin Darah pada Pederita Gagal Ginjal Kronik di RSUD Dr. Moewardi Surakarta. [Surakarta]: Fakultas IImu Kesehatan Universitas Muhammadiyah Surakarta. 2010.

21. Sumiasih. Hubungan Asupan Protein Hewani dan Nabati dengan Kadar Ureum dan Kreatinin Pasien Penyakit Gagal Ginjal Kronik Hemodialisa di RSUD Tugurejo Semarang. 2012. 
22. Yunita, Husein A, Susetyowati. Pelaksanaan Proses Asuhan Gizi Terstandar (PAGT) Terhadap Asupan Gizi dan Kadar Glukosa Darah Pasien Diabetes Mellitus Tipe 2. J Gizi Klin Indones. 2013; 10(2):82-91.

23. Dwijayanthi L. IImu Gizi Menjadi Sangat Mudah, Nutrition Made Incredible Easy. Edisi ke-2. Jakarta: EGC. 2011.

24. Hendriyani. Perilaku Pemilihan Makanan Tinggi Natrium Berpengaruh Terhadap Asupan Natrium Penderita Hipertensi di Kota Semaran. Gizi Indones. 2014; 37 (1):41-50.

25. Kamran A, Azadbakht L. Sodium Intake, Dietary Knowledge and Illness Perception of Controlled and Uncontrolled Rural Hypertensive Patients. Int J Hypertens. 2014.

26. Zhang J, Xu A, Ma J. Dietary Sodium Intake: Knowledge, Attitudes and Oractices in SHandong Province, China. PloS ONE. 2013; 8(3).

27. Grimes C, Riddel L, Nowson C. Consumer Knowledge and Attitudes to Salt Intake and Labelled Salt Information. Appetite. 2010; 53(2):189-94.

28. Palimbong S. Keefektifan Diet Rendah Garam 1 pada Makanan Biasa dan Lunak Terhadap Lama Kesembuhan Pasien Hipertensi. J Keperawatan
Muhammadiyah. 2018; 3(1).

29. Darmawan H. Asupan Natrium dan Status Gizi Terhadap Tingkat Hipertensi pada Pasien Rawat Jalan di RSUD Kota Makassar. Media Gizi Pangan. 2018; 25.

30. Atun L. Asupan Sumber Natrium, Rasio Kalium Natrium, Aktivitas Fisik dan Tekanan Darah pada Pasien. MGMI. 2014; 6 .

31. Black J, Jane H. Keperawatan Medikal Bedah Manajemen Klinis untuk Hasil yang Diharapkan. Jakarta: Salemba Medika; 2014.

32. Tovazzi M, Mazzoni V. Personal Paths of Fluid Restriction in Patients on Hemodialysis. Nephrol Nurs J. 2012; 39 (3):207-15.

33. Istanti Y. Hubungan Antara Masukan Cairan dengan INterdialytic Weight Gains (IDWG) pada Pasien Chronic Kidney Disease di Unit Hemodialisa RS PKU Muhammadiyah Yogyakarta. [Yogyakarta]: Universitas Muhammadiyah Yogyakarta; 2014.

34. Setia R, Rahmalia S, Dewi AP. Hubungan Antara Dukungan Keluarga Terhadap Kepatuhan Dalam Pembatasan Asupan Nutrisi dan Cairan pada Pasien Gagal Ginjal Kronik dengan Hemodialisa. Riau: Univ Riau. 2013. 